\title{
Carbon Emission Disclosure as Mediation of Factors Affecting Firm Value
}

\author{
Inge Indarti Alifiani ${ }^{1}$, Diah Hari Suryaningrum ${ }^{2}$ \\ \{ingealifiani03@gmail.com ${ }^{1}$, diah.suryaningrum.ak@upnjatim.ac.id²
}

Akuntansi, Universitas Pembangunan Nasional "Veteran” Jawa Timur, Surabaya, Jawa Timur, 0877503419471', Akuntansi, Universitas Pembangunan Nasional "Veteran" Jawa Timur, Surabaya, Jawa Timur, $081703170900^{2}$

\begin{abstract}
Global warming and climate change is now a common topic and a high priority scale issue in the world, especially related to carbon emissions. This study aims to obtain empirical evidence about the factors that influence the implementation of Carbon Emission Disclosure (CED) and whether CED that is voluntary reporting affects the firm value. This quantitative research using secondary data of 72 manufacturing companies listed on the Indonesia Stock Exchange in 2016 - 2018. The results of this study indicate that and profitability have a positive effect on the implementation of CED. The Sobel test results also show that CED can mediate the relationship between and profitability on firm value. The analysis also indicates that CED rating has a positive effect on firm value. This result means that investors consider the implementation of CED in the company is a positive thing and get a good market reaction.
\end{abstract}

Keywords: Carbon Emission Disclosure, firm value, environmental disclosure, voluntary disclosure

\section{Introduction}

Global warming and climate change are now becoming global topics that are being discussed hotly and are even recognized as high priority issues around the world [1]. Global warming and climate change are one of them caused by factory operations which release a lot of carbon gas emissions into the air. To cope with the increasingly severe global warming, several countries in the world made an agreement that aims to reduce global warming. One of them is the Carbon Emission Project (CDP) based in the United Kingdom in 2000. CDP worldwide in 2016 surveyed CED of companies in assessing investment risks associated with climate change and using it as a framework. CDP believes that carbon accounting and disclosure by companies will have a decisive impact on carbon management and the risk of climate change. Carbon accounting deals with the efficiency of carbon emissions in the use of raw materials, labor costs, factory overhead costs, environmental overhead costs and costs associated with standard carbon management [2].

The application of CED has many benefits not only for the company but also the environment and social, but the use of CED in Indonesia is still minimal, given the voluntary reporting. According to Suwardjono [3], management will always try to disclose private information which, according to its consideration, is of great interest to investors and shareholders, especially if the information is good news. According to Zulaikha [4], companies that are willing to disclose CED will have added value in the eyes of both foreign and local investors. The company carries out CED with several objectives including obtaining 
legitimacy from stakeholders, avoiding risks that arise for companies that produce high greenhouse gases, such as increased operating costs, reduced demand, reputation risk, legal process, as well as fines and penalties [5].

Carbon emissions in Indonesia have recently been exacerbated because of annual forest fires, and these forest fires produce carbon emissions released into the atmosphere [6]. Besides being triggered by combustion activities, CED is also triggered due to the use of energy and electricity. This power is mostly produced by industry. Manufacturing companies are noted to use large amounts of energy for their operational needs [7]. Also, fossil combustion for coal, natural gas and petroleum, which is often used for manufacturing production fuels contributes to the number of carbon emissions released into the air [8]. At the close of trading in September 2019, the agriculture sector was observed to decline the most by $1.44 \%$, and within a week the majority of palm oil company shares listed on the Indonesia Stock Exchange were found to be weakening [9].

The decline in shares of several agricultural companies after the forest fire reflects a decrease in investor confidence in the company's operational activities. According to the theory of legitimacy, the company will try to equate perceptions or assumptions that the actions taken by these entities are actions that are desirable, appropriate or following the system of norms and social values to maintain the image and sustainability of its business [10]. The application of CED can be a solution to convince the public and investors that the operational activities carried out by the company are under social values and norms, and prove that the company is responsible for the consequences of its operational activities. Contrary to the theory of legitimacy, some companies that apply CED continue to experience a decline in share prices. Among others, shares of PT Salim Ivomas Pratama Tbk fell by $1.16 \%$ in the week, and PT Bakrie Sumatera Plantations Tbk fell by $3.77 \%$ in the week.

The lack of application of CED in Indonesia can be due to several factors considered by management before implementing CED. Many previous studies that examined several factors that might influence a company when applying CED, including Paramitha and Rohman [11] revealed that there was no effect on profitability on environmental disclosure. The same results are found in a study conducted by Dewi and Yasa [12] where profitability has a negative effect on environmental disclosure. However, research conducted by Pratiwi and Sari [13], Luo et al. [14], and Gonzalez and Ramírez [15] show that there is a positive and significant effect on CED. Company size affects the level of environmental disclosure [12], while research conducted by Pratiwi [16] states that company size has no effect on carbon emissions' disclosures. Research conducted by Irwhantoko and Basuki [17] states that company size, profitability, competition, growth, debt to equity ratio, and reputation of public accounting firms have a significant effect on disclosure of carbon emissions in Indonesia. Meanwhile, the ratio of debt to equity has a significant negative effect. This contradicts the research conducted by Gonzalez and Ramírez [15] where this study stated a positive and significant relationship to carbon disclosure. Institutional ownership has a positive and significant relationship to carbon emissions' disclosures [16]. Similar results were also evidenced in the study of Zhang et al. [18] in this study it can be concluded that stakeholder power has an effect on CDP. Based on the background that has been explained, the problems that can be formulated are as follows:

1. Do company size and profitability affect the CED?

2. Does the application of CED affect the company value?

3. Does the CED mediate the relationship between firm size and profitability on firm value?

The legitimacy theory says that a company with a larger scale will be more visible in society and thus have more demands and pressure from society. To meet the demands of 
society which refers to the theory of legitimacy, the application of CEDs can be a solution to these pressures. The results of research conducted by Jannah and Muid [19], Choi et al. [20], Dewi and Yasa [12], and Luo et al. [21] stated that company size has a positive effect on carbon emissions' disclosures. Based on this description, the following hypothesis can be formed:

\section{$\mathrm{H}_{1}$ : Firm Value Has a positive effect on CED}

According to the legitimacy theory of implementing CEDs, it will increase public confidence that the company is a company that applies good social norms, because it not only prioritizes profit but also cares for the surrounding environment and participates in solving environmental issues. Qiu et al. [22] stated in his research that companies with better economies will do a wider disclosure so as to produce positive economic benefits for the company. Based on research conducted by Lu and Abeysekera [23] profitability has a positive and significant effect on environmental disclosure so that the hypothesis of the above explanation is as follows

\section{$\mathrm{H}_{2}$ : Profitability has a positive effect on CED}

The implementation of CED is voluntary, which means that this disclosure is carried out by the company outside of what is required by accounting standards or regulations of the regulatory body [3]. This disclosure assists global investors in making decisions regarding the performance and efforts of natural companies to account for the adverse impacts of their operational activities in terms of carbon emissions and climate change. Although this CED is still minimally applied by companies in Indonesia, several studies have proven that the application of CED has a significant effect on companies. According to the description above, it can be concluded that investors have received positive signals expressed by companies through carbon emissions' disclosures

Several studies have revealed that carbon emissions' disclosures have a positive and significant effect on firm value [1], [24], [25]. Different from several studies previously mentioned, several studies actually stated that there was no effect between carbon emissions' disclosures on firm value. Research conducted by Cotter and Najah [26] states that the CED made by CDP has no effect on adding firm value. Matsumura et al. [27] also said that carbon emissions are negatively related to corporate value. However, the research results are consistent that carbon emissions and their disclosures are used by the capital market in the valuation of companies. According to the description above, the following hypothesis can be formulated.

\section{$\mathrm{H}_{3}$ : CED affects the firm value}


Some studies say that firm size and profitability do not influence firm value [28], [29]. These factors need to be supported by non-financial information that can clarify mandatory reporting. That way, investors will have more trust and believe that the company is the right place to invest. CED can be a solution for disclosure of information outside the company's mandatory report.

\section{H4: CED mediates the effect of firm size on firm value \\ H5: CED mediates the effect of profitability on firm value}

Based on the explanation that has been done and the hypotheses that have been formed. The framework of this research is as follows

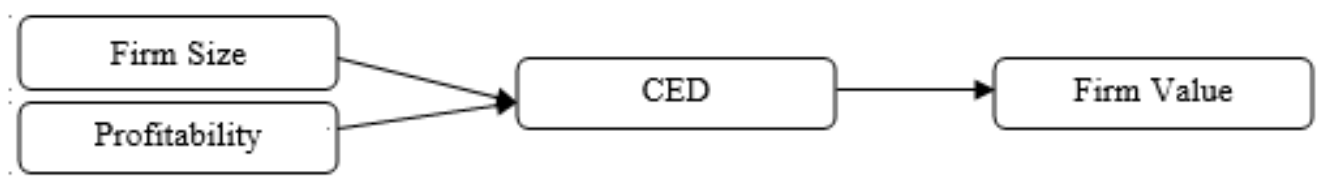

Fig.1. Research Framework.

\section{Method}

\subsection{Population and Sample}

The population in this study uses manufacturing companies listed on the Indonesia Stock Exchange (IDX) during 2016-2018. The method used to select samples is purposive sampling with several criteria, including:

1. Manufacturing companies listed on the IDX and have never been delisted in 20162018

2. The company provides secondary data in the form of financial reports and annual reports that can be downloaded from the IDX or the company's official website from 2016-2018

3. Companies that did not experience losses during 2016-2018

4. Companies that present financial statements in rupiah

From the criteria above, 72 sample companies were set with a three year research period. The research subjects in this study are firm size, profitability, and CED (CED). This type of quantitative research and the data used in this study are secondary data in the form of financial statements and annual reports of the company which can be downloaded through the Indonesia Stock Exchange website (www.idx.co.id) or the official website of each company. The data analysis technique used is the path analysis technique (Path Analysis) using SPSS 25.

\subsection{Measures}

Firm Size. Company size in this study is measured using the measurement method used by Dewi and Yasa [12] with the natural logarithm (ln) of total assets. 


\section{Firm Size $=(L n)$ total assets}

(1)

Profitability. Profitability in this study uses Return on Assets (ROA) which is measured by dividing profit after tax by total assets [20]. This ratio illustrates the company's ability to manage operational activities to generate future profits. The formula used to calculate profitability is stated in formula 2 .

$$
\text { ROA }=\frac{\text { Income After Tax }}{\text { Total assets }}
$$

CED (CED). CED is measured using five main indicators issued by the Carbon Development Program (CDP) which are further developed into 18 items that describe the five indicators by Choi et al., In 2013. The indicator table for measuring CED will be attached in the attachment.

Firm Value. Usually firm value is measured using Tobin's Q. The calculation of company value in this way is considered to provide better information because Tobin's $\mathrm{Q}$ includes various elements of debt and company shares, not only company equity is included but company assets are also included in Tobin's Q elements. Tobin's Q formula to be used is described in formula 1

$$
\text { Tobin's } Q=\frac{\text { MVE }+ \text { Total Liabilities }}{\text { Total Activa }}
$$

\section{Results And Discussion}

\subsection{Results}

Based on the SPSS test results in table 1, the regression equation that can be formed is

$$
\mathrm{Z}=-5,025+4,076 \times 1+0,150 \times 2+\mathrm{e} 1
$$

From the significant figures in Table 1 it can be concluded that there is a partial effect between the research variables, it can be found that firm size, profitability affect CED with a smaller significant value of 0.05 .

\begin{tabular}{cccccc}
\multicolumn{7}{c}{ Tabel 1. T- test Regression 1 } \\
\hline Model & $\mathrm{B}$ & Error Std. & Beta & $\mathrm{T}$ & Sig. \\
\hline (Constant) & $-5,025$ & 1,343 & & $-3,741$ &, 000 \\
X1 & 4,076 & 1,237 &, 315 & 3,295 &, 001 \\
X2 &, 150 &, 055 &, 276 & 2,734 &, 007 \\
\hline
\end{tabular}

Source: SPSS Processed Data (2020) 
Based on the SPSS test results in table 2, the regression equation that can be formed is as follows.

$$
\mathrm{Y}=3,419-0,653 \times 1-0,218 \times 2+0,149 \mathrm{z}+\mathrm{e} 2
$$

From table 2, CED (Z) has a significant value of $0.007<0.05$, it can be concluded that CED $(Z)$ has a significant effect on firm value $(Y)$ with a positive influence direction which illustrates that an increase in CED will follow an increase in the value of the company.

Tabel 2. T- test Regression 2

\begin{tabular}{cccccc}
\hline Model & B & Error Std. & Beta & t & Sig. \\
\hline (Constant) & 3,419 & 0,477 & & 7,175 & 0,000 \\
X1 & $-0,653$ & 0,124 & $-0,371$ & $-5,259$ & 0,000 \\
X2 & $-0,218$ & 0,092 & $-0,156$ & $-2,374$ & 0,019 \\
Z & 0,149 & 0,055 & 0,196 & 2,732 & 0,007 \\
\hline \multicolumn{5}{c}{ Source: SPSS Processed Data (2020) }
\end{tabular}

According to table 3, the results of the t-test and the Sobel test show a number higher than the table. It indicates that CED provides a mediating effect on and profitability on firm value.

\begin{tabular}{cccc}
\multicolumn{4}{c}{ Tabel 3. Sobel Test Result } \\
\hline Model & TValue & Description & Conclusion \\
\hline $\mathrm{X} 1-\mathrm{Z}-\mathrm{Y}$ & 2,037 & $\mathrm{t}_{\text {value }}>1,652$ & Accepted \\
$\mathrm{X} 2-\mathrm{Z}-\mathrm{Y}$ & 1,860 & $\mathrm{t}_{\text {value }}>1,652$ & Accepted \\
\hline \multicolumn{4}{c}{ Source: SPSS Processed Data $(2020)$}
\end{tabular}

\subsection{Discussion}

Effect of firm size on CED. Based on the test results in table 1 obtained a significant value of the firm size variable (X1) in influencing CED $(Z)$ is smaller than the criteria set 0.05 , which is equal to 0.001 . These results indicate that $\mathrm{H}_{1}$ is accepted and it can be concluded that firm size has a significantly positive effect on CED. This result means that the larger the size of the company, the better the company will be in disclosing carbon emissions.

These results are following the theory of legitimacy, which says that large-scale companies will be more visible in the community. The company has many demands and pressures from the community. So, to meet these demands, the company makes some disclosures that are deemed necessary regarding responsibility for its operational activities through CED. The results of this study also support the opinions of previous studies conducted by Jannah and Muid [17], Choi et al. [18], Luo et al. [20], and Dewi and Yasa [19]. They state that firm size has a positive influence on the implementation of CED.

Effect of profitability on CED. Based on the results of the t-test on table 1 , the significance value for the profitability variable $(\mathrm{X} 2)$ is smaller than the specified criterion $(0.05)$, which is 0.007 . This value shows that there is a significant effect between profitability and CED with the direction of positive influence and $\mathrm{H}_{2}$ received. These results reinforce the statement of Pradini and Kiswara [23] which states that companies with larger profits will be easier to implement CED because they are better able to meet reporting costs that are considered small when compared to the company's profit. It also supports research conducted by $\mathrm{Lu}$ and Abeysekera [15] which states that profitability has a positive and significant influence on environmental disclosure. 
Companies with high profitability will make broader disclosures to increase the trust of the public and investors. This result is under the theory of legitimacy in which the public will believe that the company operates following prevailing norms and social norms if not only by prioritizing profits but also by caring for the environment. By implementing a CED, the company can also produce positive economic benefits for the company because of the trust it has gained from the public and investors.

Effect of CED on firm value. Based on the results of the t-test in table 2, the CED variable shows a significant value of 0.007 or smaller than the established criteria that is 0.05 and has a positive direction of influence. This result indicates that CED partially has a positive and significant effect on firm value, and $\mathrm{H}_{3}$ is accepted. The results also show that information in the form of voluntary CED is responded well by the market and becomes one of the considerations of investors to make investment decisions so that the higher the application of CED in the company, the value of the company will also increase.

These results are also supported by several previous studies such as those conducted by Saka and Oshika [1], Anggraeni [11], Clarkson et al. [12]. They also said that CED had a positive and significant influence on firm value. This relation indicates that investors responded positively to the efforts made by management in making voluntary disclosures. In line with the signal theory, which says that according to management, if the information will be of interest to investors, the manager will disclose the private information [3].

Effect of firm size on firm value through CED. The magnitude of the direct effect of on firm value is -0.3371 , while the magnitude of the indirect effect is 0.0617 . This value means that there is full mediation because the indirect effect is greater than the direct effect. In the Sobel test calculation results, $\mathrm{t}$-value $=2.037>\mathrm{t}$-table $=1.652$ in the one-tailed test with a significance level of 0.05 . Then it can be concluded that the effect of mediation occurs. The results of this study indicate that the CED variable $(\mathrm{Z})$ mediates the relationship between (X1) and firm value $(\mathrm{Y})$. This result means that the hypothesis stating that CED mediates the effect of firm size on firm value (H4) is accepted.

The greater the company's assets will illustrate how the company has reached maturity. Companies that are at an adult stage will have positive cash flow and are expected to be profitable in a relatively long period of time [24]. Therefore, a company with a larger size will be more attractive to investors and easier to get funding sources so that along with increasing firm size, the value of the company will also increase. The increase in firm size will be accompanied by an increase in operations as well. With high operational activities, the company will produce more waste from production that can pollute the environment. This will certainly have a bad impact on the company's image.

In harmony with the theory of legitimacy, larger-scale companies will be more visible in society and will receive more pressure and demands from both investors and the public. In meeting with this pressure, management applies CED as a form of accountability for its operational activities. The management effort is proven to have a good impact on the company's value. This effort can be seen from the increase of $24.6 \%$ on the direct effect of firm size on firm value when CED is added as a moderating variable. The investors will appreciate a large-scale company that applied a good CED. This appreciation is seen in the increase of the company shares. Thus, it will also be accompanied by an increase in firm value. 
Effect of profitability on firm value through CED. In the Sobel test calculation results, the calculated value for the effect of CED mediation on the relationship between profitability and firm value is $1,860>\mathrm{t}$ table $=1.652$. Then it can be concluded that the effect of mediation occurs. The results of this study indicate that the CED variable $(Z)$ mediates the relationship between profitability (X2) and firm value (Y). This value means that the hypothesis stating that CED mediates the effect of profitability on firm value (H5) is accepted.

The application of CED in a company will make a company's image improve. Investors will be more interested in companies that have a good image in the community because it has an impact on high consumer loyalty to the company's products. In this study it shows that there is a significant influence between profitability and firm value when going through CED. This is in line with the signal theory that if the company has information that makes the company better, they will deliver it with the aim of gaining benefits from that information. This result indicates that when the company is responsible to stakeholders for carbon emissions resulting from its operational activities to make a profit, the company will simultaneously increase the value of the company. However, this does not mean that if the CED is not implemented, then the value of the company will decrease because the mediation for this pathway is partial mediation where the indirect effect is smaller than the direct impact. So, if the company's profitability is good, without the implementation of CED, the company's value will still be good.

\section{Conclusion}

Firm size and profitability are factors that influence companies in implementing CED, the greater and higher the company's profit, the higher the carbon emissions generated during their operational processes. Companies with large size and profitability will be more likely to apply CED because the cost of implementing CED is considered small when compared to their profit. The firm size and profitability influence firm value. This result means that the larger the company and the higher the profit, the more it attracts investors to invest in the company. In turn, it is reflected in the increasing value of the company as well. With the addition of CED as a moderating variable can strengthen the relationship, it can be seen from the results of the calculation of the indirect effect after adding a CED variable that has a value higher than its direct influence. It can be concluded that the implementation of CED can help increase the value of the company because CED as a voluntary disclosure made by the company can attract investors to invest in the company and increase the value of the company.

Limitations and constraints experienced by researchers while compiling this research is not all companies implementing CEDs, this makes the sample of this study limited so that it cannot describe the actual conditions. Some companies that implement CEDs are still reporting it as it is, even sometimes the information is difficult to find both in annual reports and other reports on the company's web. So that researchers suggest that the research sample can be carried out more broadly, not only manufacturing companies but also other sectors. This is intended so that further research can be more representative and general in nature considering that this CED is voluntary and not all companies apply CEDs so that the more samples the more it will be able to describe the application of CEDs to the company. For sobel test, it is done by counting manually and cannot be done with statistical applications. So that it allows for human error. 


\section{References}

[1] Saka, C. Oshika, T.: Disclosure effects, carbon emissions and corporate value. Sustainability Accounting, Management and Policy Journal. Vol. 5, no. 1, pp. 22-45 (2014), doi: 10.1108/SAMPJ-09-2012-0030.

[2] Ratnatunga, J. T. D. Balachandran, K. R.: Carbon business accounting: The impact of global warming on the cost and management accounting profession. Journal of Accounting, Audit, Finance. Vol. 24, no. 2, pp. 333-355 (2009), doi: 10.1177/0148558X0902400208.

[3] Suwardjono.: Teori Akuntansi Perekayasaan Pelaporan Keuangan. edisi ketiga. cetakan kelima. BPFFE, Yogyakarta (2014).

[4] Zulaikha, A. P.: Analisis Pengungkapan Emisi Gas Rumah Kaca. Diponegoro Journal of Accounting. vol. 13, no. 2, pp. 155-175 (2016).

[5] Berthelot, S. Robert, A. M.: Climate Change Disclosures: An Examination of Canadian Oil and Gas Firms. Issues In Social And Environmental Accounting. Vol. 5, no. 2, pp. 106 (2011), doi: 10.22164/isea.v5i2.61.

[6] Idhom, A.: Penyebab dan Akibat Kebakaran Hutan di Kalimantan Hingga Sumatera. tirto.id (2019). https://tirto.id/penyebab-dan-akibat-kebakaran-hutan-di-kalimantan-hingga-sumatera-eic3 (accessed Nov. 25, 2019).

[7] Kusumawardhani, N.: Emisi Karbon Dioksida Tahun Ini Tembus Angka 40,9 Miliar Ton. republika.co.id. (2018). https://republika.co.id/berita/trendtek/sains-trendtek/18/12/06/pjbebi349emisi-karbon-dioksida-tahun-ini-tembus-angka-409-miliar-ton (accessed Nov. 25, 2019).

[8] Firman, T.: Emisi Bahan Bakar Fosil Dorong Bumi Ke Jurang Kiamat. tirto.id. (2017). https://tirto.id/emisi-bahan-bakar-fosil-dorong-bumi-ke-jurang-kiamat-cz8d (accessed Nov. 23, 2019).

[9] Mustika, N.: Saham Perusahaan Sawit Turun Akibat Kebakaran Hutan dan Lahan (Karhutla). Finansialku.com. (2019). https://www.finansialku.com/kebakaran-hutan-dan-lahan/ (accessed Nov. 23, 2019).

[10] Purwanto, A.: Pengaruh Tipe Industri, Ukuran Perusahaan, Profitabilitas terhadap Corporate Social, Responsibility. Jurnal Akuntansi dan Auditing. vol. 8, no. 1, pp. 12-29 (2011).

[11] Paramitha, B. W. and Rohman, A.: Pengaruh Karakteristik Perusahaan Terhadap Enviromental Disclosure. Diponegoro Journal of Accounting. Vol. 3, pp. 188-198 (2014).

[12] Dewi, I. A. P. O. Y. and Yasa, G. W.: Pengaruh Ukuran Perusahaan, Profitabilitas, Tipe Industri, Dan Kinerja Lingkungan Terhadap Environmental Disclosure. E-Jurnal Akunt. Univ. Udayana. Vol. 20, no. 3, pp. 2362-2391 (2017).

[13] Pratiwi, P. C. and Sari, V. F.: Pengaruh Tipe Industri, Media Exposure dan Profitabilitas terhadap CED. Journal WRA. V. F.ol. 4, no. 2, pp. 829-844 (2016).

[14] Luo, L. Tang, Q. and Lan, Y. C.: Comparison of propensity for carbon disclosure between developing and developed countries. Accounting Research. Journal. Vol. 26, no. 1, pp. 6-34 (2013), doi: http://dx.doi.org/10.1108/MRR-09-2015-0216.

[15] Gonzalez, J. M. G. and Ramírez, C. Z.: Voluntary carbon disclosure by Spanish companies: an empirical analysis. International Journal Climate Change Strategies and Management. Vol. 8, no. 1, pp. 57-79 (2016).

[16] Pratiwi, D. N.: Implementasi CED di Indonesia. Jurnal Ilmiah Akuntansi dan Bisnis. Vol. 13, no. 2, pp. 101 (2018), doi: 10.24843/JIAB.2018.v13.i02.p04.

[17] Irwhantoko, V. and Basuki, B.: CED: Studi pada Perusahaan Manufaktur Indonesia. Jurnal Akuntansi dan Keuangan. Vol. 18, no. 2, pp. 92-104 (2016), doi: 10.9744/jak.18.2.92-104.

[18] Zhang, S. Mcnicholas, P. Birt, J. and Zhang, M. S.: Australian Corporate Responses to Climate Change: The Carbon Disclosure Project. RMIT Accounting for Sustainability. Conference. (2012).

[19] Jannah, R. and Muid, D.: Analisis faktor-faktor yang mempengaruhi CED pada perusahaan di Indonesia. Diponegoro Journal of Accounting., vol. 3, no. 2, pp. 1-11 (2014).

[20] Choi, B. B. Lee, D. and Psaros, J.: An analysis of Australian company CEDs. Pacific Accounting Review., vol. 25, no. 1, pp. 58-79 (2013), doi: 10.1108/01140581311318968.

[21] Luo, L. and Tang, Q.: Carbon tax, corporate carbon profile and financial return. Pacific Accounin. 
Review., vol. 26, no. 3, pp. 351-373 (2014), doi: 10.1108/PAR-09-2012-0046.

[22] Qiu, Y. Shaukat, A. and Tharyan, R.: Environmental and social disclosures: Link with corporate financial performance. British Accounting Review., vol. 48, no. 1, pp. 102-116 (2016), doi: 10.1016/j.bar.2014.10.007.

[23] Lu, Y. and Abeysekera, I.: Stakeholders' power, corporate characteristics, and social and environmental disclosure: Evidence from China. Journal of Cleaner Production., vol. 64, pp. 426436 (2014), doi: 10.1016/j.jclepro.2013.10.005.

[24] Anggraeni, D. Y.: Pengungkapan Emisi GRK, Kinerja Lingkungan, dan Nilai Perusahaan. Jurnal Akuntansi Dan Keuangan Indonesia., vol. 12, no. 2, pp. 188-209 (2015).

[25] Clarkson, P. M. Li, Y. Richardson, G. D. Vasvari, F. P.: Does it really pay to be green? Determinants and consequences of proactive environmental strategies. Journal of Accounting and Public Policy., vol. 30, no. 2, pp. 122-144 (2011), doi: 10.1016/j.jaccpubpol.2010.09.013.

[26] Cotter, J. Najah, M. M.: Institutional investor influence on global climate change disclosure practices. Australian Journal of Management., vol. 37, no. 2, pp. 169-187 (2012), doi: $10.1177 / 0312896211423945$.

[27] Matsumura, E. M. Prakash, R. Vera-Muñoz, S. C.: Firm-value effects of carbon emissions and carbon disclosures. Accounting Review., vol. 89, no. 2, pp. 695-724 (2014), doi: 10.2308/accr50629.

[28] Kodongo, O. Maina, L. Mokoteli, M. T.: Capital structure, profitability and Firm Value: panel evidence of listed firms in Kenya. African Finance Journal., vol. 17, no. 1, pp. 1-20 (2015).

[29] Hestinoviana, V. Suhadak. Handayani, S. R.: The Influence Of Profitability, Solvability, Asset Growth, and Sales Growth Toward Firm Value (Empirical Study on Mining Companies Which Listed on Indonesia Stock Exchange). Jurnal Universitas Brawijaya., vol. 4, no. 1 (2013).

[30] Suwardika, I. Mustanda, I.: Pengaruh Leverage, Ukuran Perusahaan, Pertumbuhan Perusahaan, Dan Profitabilitas Terhadap Nilai Perusahaan Pada Perusahaan Properti. E-Jurnal Manajemen Unud., vol. 6, no. 3, pp. 1248-1277 (2017). 